\title{
KARAKTERISTIK DAN MOTIVASI WISATAWAN MANCANEGARA YANG BERKUNJUNG KE PANTAI LAKEY, DOMPU, NUSA TENGGARA BARAT
}

\author{
Muhammad Fitrullah$^{1}$, Ni Made Oka Karini' ${ }^{2}$, Ni Putu Eka Mahadewi ${ }^{3}$ \\ ${ }^{1}$ Email : fitrahib29@gmail.com \\ Program Studi Industri Perjalanan Wisata, Fakultas Pariwisata, Universitas Udayana \\ ${ }^{2}$ Email : okakarini@gmail.com \\ Program Studi Industri Perjalanan Wisata, Fakultas Pariwisata, Universitas Udayana \\ ${ }^{3}$ Email : eka.mahadewi23@gmail.com \\ Program Studi Industri Perjalanan Wisata, Fakultas Pariwisata, Universitas Udayana
}

\begin{abstract}
Lakey Beach has potential that is not shared by many other tourist attractions such as lefthand wave sweeping. Not only that, the life of the local people around Lakey Beach tourist attraction which is quite unique and still preserves customs is a special attraction for tourists who visit. For this reason, we want to know the Characteristics, Motivation of foreign tourists visiting Lakey Beach.The sampling technique uses the slovin formula and purposive sampling by distributing 100 open questionnaires to foreign tourists visiting Lakey Beach tourist attractions. The data analysis technique used in this research is descriptive qualitative is a technique that describes and interprets the meaning of the data that has been collected. Based on the results of research characteristics of foreign tourists visiting Lakey Beach based on age 15-30 years old 57 people (57\%), the area of origin of Australia 41 people (41\%), male gender 5 people (56\%), the status of recreational trips / holidays 98 people (98\%), sources of friends / family information 54 people (54\%), frequency of visiting 63 people (63\%), home stay accommodations 59 people (59\%). While the intrinsic motivation of foreign tourists on the indicator want to have fun score of 4.2 (agree), want to channel the hobby of surfing / surfing the score of 4.09 (agree) has the highest liker score, while the lowest liker score on the indicator wants to visit friends / liker's family score 2.15 (disagree). Whereas the extrinsic motivation of foreign tourists on the highest liker score indicator is the leisure time score of 4.27 liker (strongly agree), while the indicator with the lowest liker score is conducting a comparative study of liker score 2.16 (disagree).
\end{abstract}

\begin{abstract}
Abstrak: Pantai Lakey memiliki potensi yang tidak banyak dimiliki oleh daya tarik wisata lainnya seperti halnya sapuan ombak kidal. Bukan hanya itu, kehidupan masyarakat lokal sekitar daya tarik wisata Pantai Lakey yang terbilang cukup unik dan masih mejaga adat istiadat menjadi daya tarik tersendiri bagi wisatawan yang berkunjung. Untuk itu ingin diketahui Karakteristik, Motivasi wisatawan mancanegara yang berkunjung ke Pantai Lakey. Teknik penentuan sampel menggunakan rumus slovin dan purposive sampling dengan membagikan 100 kuisioner terbuka kepada wisatawan mancanegara yang berkunjung ke daya tarik wisata Pantai Lakey. Teknik analisis data yang digunakan dalam penelitian ini adalah deskriptif kualitatif merupakan suatu teknik yang menggambarkan dan menginterpretasikan arti data-data yang telah terkumpul. Berdasarkan hasil penelitian karaktristik wisatawan mancanegara yang berkunjung ke Pantai Lakey berdasarkan umur 15-30 tahun 57 orang (57\%), daerah asal Australia 41 orang (41\%), jenis kelamin laki-laki 5 orang (56\%), status perjalanan rekreasi/ liburan 98 orang (98\%), sumber informasi teman/ keluarga 54 orang (54\%), frekuensi berkunjung 63 orang (63\%), akomodasi home stay 59 orang (59\%). Sedangkan motivasi intrinsik wisatawan mancanegara pada indikator ingin bersenang-senang skor liker 4,2 (kuat), ingin menyaluarkan hobi bermain selancar/ surfing skor liker 4,09 (setuju) memiliki skor liker tertinggi, sedangkan skor liker terendah pada indikator ingin mengunjungi teman/ keluarga skor liker 2,15 (tidak setuju). Sedangkan pada motivasi ekstrinsik wisatawan mancanegara pada indikator skor liker tertinggi adalah adanya waktu luang skor liker 4,27 ( sangat setuju), sedangkan indikator dengan skor liker terendah adalah melakukan studi banding skor liker 2,16 (tidak setuju).
\end{abstract}

Keywords : characteristics, motivation, foreign tourists, lakey beach. 
Jurnal IPTA

Vol. 7 No. 2, 2019

p-ISSN : 2338-8633

e-ISSN : 2548-7930 


\section{PENDAHULUAN}

Pariwisata merupakan aktivitas seseorang melakukan perjalanan ke suatu tempat di luar lingkungan biasanya untuk kurang dari satu tahun dan tujuan umumnya adalah perjalanan dan bukan untuk mendapatkan penghasilan di tempat yang akan dikunjunginya. Pariwisata sendiri jika dilihat dari sisi subjeknya, sudah menjadi kebutuhan umat manusia di seluruh dunia karena pariwisata merupakan salah satu cara untuk refreshing atau beristirahat sejenak dari rutinitas harian yang biasanya jenuh dan melelahkan. Sedangkan jika dilihat dari objeknya, pariwisata merupakan salah satu hal yang terus dikembangkan karena memiliki pengaruh yang sangat signifikan dalam peningkatan pendapatan melalui penerimaan devisa dan juga memberikan dampak yang sangat besar bagi pelaku pariwisata terutama para penyedia jasa di daya tarik wisata yang dituju para wisatawan.

Berbicara tentang pariwisata, tentu kita tidak bisa lepas dari kajian terhadap wisatawan sebagai pelaku kegiatan wisata.Pertanyaan penting yang harus dijawab adalah apakah yang mendorong seseorang untuk melakukan kegiatan wisata. Hal ini tentu memiliki kaitan langsung dengan motivasi orang untuk berwisata. Motivasi berwisata tentu saja memiliki peranan penting dalam kegiatan berwisata. Keinginan untuk melakukan perjalanan dipengaruhi oleh adanya rangsangan baik yang berasal dari dalam maupun yang berasal dari luar. Rangsangan dari dalam berasal dari adanya kesadaran akan sesuatu yang kurang dalam kehidupan sehari- hari. Sedangkan rangsangan dari luar berasal dari adanya iklan, percakapan dengan teman, dan berbagai hal yang memunculkan kesadaran seseorang untuk melakukan kegiatan berwisata (Gartner: 1996:5).

Indonesia sebagai salah satu negara yang besar dan memiliki keanekaragaman budaya dan juga agama yang dianut oleh rakyatnya, tentu memiliki banyak daya tarik wisata alam yang tersebar di seluruh penjuru Indonesia. Salah satunya di Provinsi Nusa Tenggara Barat tepat di Kabupaten Dompu Desa Hu'u memiliki daya tarik wisata pantai yang dimana sudah terkenal hingga ke mancanegara karena menjadi salah satu tempat terbaik untuk bermain surfing, bukan hanya ombaknya yang menjadikan Lakey sangat pantas dikunjungi akan tetapi pantainya yang masih asri serta kehidupan masyarakat yang masih mempertahankan kebudayaan lokalnya sangat pantas untuk dikunjungi. Kabupaten Dompu merupakan kabupaten yang terletak di timur pulau Sumbawa Provinsi NTB, Kabupaten dompu memiliki banyak keanekaraman budaya, sejarah serta wisata alamnya, akan tetapi yang paling dikenal adalah daya tarik wisata pantai Lakey. Lakey merupakan pantai yang dimana sering diadakannya event surfing nasional bahkan internasional, dan lakey termasuk sebagai salah satu tempat paling diminati oleh wisatawan yang memiliki minat khusus, seperti pecinta surfing. Akan tetapi lakey juga tidak hanya unggul akan ombaknya, tetapi Lakey juga memili pantai dan pasir yang bersih dan sangat menarik untuk dikujungi. Lakey juga didukung dengan fasilitas pendukung kegiatan pariwisata didalamnya. Seperti, hotel, homestay, resort, bar, restoran, toilet umum dan juga aksesibilitas yang memadai. Akantetapi kekurangan pantai lakey adalah dari jarak tempuh dan letaknya yang jauh dari pusat kota, sehingga menyulitkan wisatawan untuk mendapatkan informasi yang akurat tentang pariwisata Lakey atau bahkan untuk berkunjung menggunakan kendaraan pribadi cukup sulit.

Perkembangan jumlah kunjungan wisatawan ke Daya tarik wisata panta Lakey dari tahun mengalami perkembangan yang cukup baik. Pada tahun 2015 tingkat kunjungan wisatawan mancanegara mengalami peningkatan sebesar $7,7 \%$ dan tahun 2016 semakin meningkat yaitu sebesar 9,2\% sedangkan di tahun 2017 kembali menurun sebesar 4,7\% dan pada tahun 2018 jumlah kunjungan wisatawan mancanegara kembali meningkat sebesar $11,7 \%$ menurut dinas pariwisata Kabupaten Dompu diwakili oleh bapak Kabip promosi dan pemasaran mengatakan hal tersebut yang menyebabkan turunnya jumlah kunjungan wisatawan di pantai Lakey karena adanya bencana alam banjir bandang yang melanda daerah Dompu dan Bima menyebabkan jumlah kunjungan wisatawan mancanegara yang berkunjung ke daya tarik wisata pantai Lakey menurun di akhir tahun 2017. Karena menerut Dinas Pariwisata Kabupaten Dompu, banjir bandang menyebabkan aktifitas pariwisata Kabupaten Dompu sangat terhambat, salah satunya 
masalah aksesibilitas serta transportasi dari airport menuju ke daya tarik wisata pantai Lakey. Meskipun di tahun 2017 jumlah kunjungan wisatawan mancanegara menurun, akan tetapi di tahun 2018 jumlah kunjungan wisatawan mancanegara kembali meningkat, menurut Dinas Pariwisata Kabupaten Dompu, meningkatnya jumlah wisatawan di akhir tahun 2018 disebabkan oleh adanya kiriman wisatawan dari Lombok, Khususnya Lombok Utara Provinsi Nusa Tenggara Barat diakibatkan adanya bencana alam gempa bumi yang melanda daerah NTB khususnya daerah Lombok dan sekitarnya. Menyebabkan wisatawan yang menetap atau berkunjung ke Lombok memilih transit atau berkunjung ke daerah Dompu Khususnya di daya tarik wisata pantai Lakey.

Wisatawan mancanegara yang berkunjung ke daya tarik wisata Pantai Lakey di dominasi oleh wisatawan berkewarganegaraan Australia dan di susul wisatawan mancanegara yang berasal dari beberapa negara di bagian Eropa, selanjutnya wisatawan yang berasal dari beberapa Negara Bagian Amerika, dan juga wisatawan yang berasal dari beberapa negara Asia. Bukan tanpa alasan, daya tarik wisata Pantai Lakey didominasi oleh wisatawan Australia dan juga ada beberapa Wisatawan yang bersal dari negara-negara bagian Eropa, karena Pantai Lakey memiliki potensi yang jarang dimiliki oleh daya tarik wisata lainnya, yaitu sapuan ombak ke kiri serta keasrian dan keindahan alam yang dimiliki Pantai Lakey menjadi daya tarik tersendiri bagi wisatawan yang memiliki keahlian khusus dalam bermain selancar atau mengasah kemampuan untuk bermain selancar (surfing). Bukan hanya itu, banyak aktfitas wisata yang dapat wisatawan lakukan di Pantai Lakey. Seperti halnya, bermain Kano, mengelilingi pantai Lakey dengan menggunakan perahu motor sewaan dan bersantai menikmati keindahan alam pantai Lakey. Potensi alam yang dimiliki daya tarik wisata pantai Lakey memang menjadi daya tarik tersendiri bagi wisatawan yang ingin berkunjung ke pantai Lakey. Akan tetapi bukan hanya karena daya tarik wisata alamnya, Keunikan kehidupan masyarakat lokal di sekitaran daya tarik wisata pantai Lakey yang masih menjaga adat istiadat juga menjadi daya tarik tersendiri bagi wisatawan yang berkunjung ke daya tarik wisata pantai Lakey.

Masyarakat Desa Hu'u sendiri masih terbilang memiliki gaya hidup tradisional, akan tetapi tidak sedikit masyarakat desa Hu'u yang memiliki kemampuan berbahasa asing, khususnya bahasa inggris. Baik di kalangan orang tua, remaja hingga anak- anak. Oleh karena itu, daya tarik wisata pantai Lakey bukan hanya dikenal sebagai salah satu tempat bermain selancar di dunia bahkan salah satu tempat diadakannya kompetisi tingkat internasional, akan tetapi banyak akfititas wisata yang dapat dilakukan di daya tarik wisata pantai Lakey, bahkan gaya hidup masyarakat di sekitaran daya tarik wisata Pantai Lakey menjadi daya tarik tersendiri bagi wisatawan yang berkunjung ke daya tarik wisata pantai Lakey.

Untuk menjaga eksistensi serta meningkatkan jumlah kunjungan wisatawan yang berkunjung ke daya tarik wisata Pantai Lakey, Maka pada awal tahun 2019 pemerintah Kabupaten Dompu Khususnya dinas pariwisata Dompu mengatakan akan melakukan upaya promosi dan juga mengadakan beberapa event seperti pada tahun-tahun sebelumnya. Adapun beberapa daftar Event yang sudah diselenggaran sebelumnya. Seperti, Event Surfng internasional Pada tahun 2013 Rip curl international pro diadakan langsung oleh Rip curl bekerja sama dengan pemerintah daerah Kabupaten Dompu, event tersebut diikuti oleh ratusan atlet-atlet baik dalam negeri maupun Luar negeri, Pada tahun 2014 Event Lakey Peak Pro ini adalah event surfing international diadakan oleh Pemerintah daerah Kabupaten Dompu. Pada tahun 2017 kembali digelar event surfing internasional yaitu, Rip curl Asian Tour QS yang diadakan langsung oleh perusahaan Rip curl dan pada tahun 2018 pemerintah daerah Kabupaten Dompu mengadakan Event Tambora menyapa dunia atau Pesona Tambora sebagai langkah promosi dan meningkatkan jumlah wisatawan ke setiap daya tarik wisata yang ada di Kabupaten Dompu Khususnya, Tambora dan daya tarik wisata Pantai Lakey. Untuk event yang akan datang, menurut pemerintah daerah khususnya Dinas Pariwisata Kabupaten Dompu akan menyelenggarakan event, akan tetapi event akan lebih menarik lagi agar kembali menarik jumlah wisatawan yang 
berkunjung ke daya tarik wisata pantai Lakey dengan tujuan untuk meningkatkan lagi jumlah kunjungan wisatawan mancanegara yang berkunjung ke daya tarik wisata pantai Lakey.

\section{METODE PENELITIAN}

Penelitian ini dilakukan di daya tarik wisata pantai Lakey Desa Hu'u adalah sebuah Kecamatan yang terletak di Kabupaten Dompu, Nusa Tenggara Barat, Indonesia. Kecamatan ini terletak di pulau Sumbawa berjarak sekitar 25 kilometer dari pusat Kota Kabupaten Dompu ke arah selatan. Pusat pemerintahannya berada di Desa Rasabou Kecamatan Hu'u. Kecamatan Hu'u sangat terkenal dengan destinasi wisata pantai dan popular sebagai tempat wisata bahari terutama olahraga selancar (surfing).

Adapun jenis data yang digunakan dalam penelitian ini dibagi menjadi dua, yaitu data kualitatif dan kuantitatif. Data kualitatif dalam penelitian ini adalah data yang digambarkan dengan kata-kata, informasi-informasi, uraianuraian atau keterangan yang relevan yang ada hubungannya dengan penelitian yang diperoleh melalui wawancara penyebaran media kuesioner kepada wisatawan yang mengunjungi daya tarik wisata pantai Lakey di Desa Hu'u Kabupaten Dompu dalam hal mengenai karakteristik, motivasi wisatawan yang berkunjung ke daya tarik wisata pantai Lakey. Sedangkan data kuantitatif Dalam penelitian ini data yang diukur secara langsung berupa angka-angka, seperti jumlah kunjungan wisatawan nusantara yang berkunjung ke daya tarik wisata pantai Lakey di Desa Hu'u Kabupaten Dompu, umur wisatawan yang berkunjung, jumlah kunjungan ke daya tarik wisata pantai Lakey. Teknik pengumpulan data dalam penelitian ini melalui observasi, penyebaran kuesioner, wawancara, dan studi kepustakaan. Dalam penelitian ini yang dijadikan sampel yaitu wisatawan yang berkunjung ke daya tarik wisata pantai Lakey di Kabupaten Dompu. Untuk menentukan jumlah sampel dalam penelitian ini berdasarkan total jumlah wisatawan yang berkunjung ke daya tarik wisata pantai Lakey. penentuan ukuran sampel dalam penelitian ini dilakukan menggunakan rumus Slovin dalam Abubakar(2009).

Teknik analisis data dalam penelitian ini
Menurut Sugiyono (2000:244) analisis data adalah proses mencari dan menyusun data yang diperoleh dari hasil wawancara, catatan lapangan, dan bahan- bahan baik secara sistematis sehingga mudah dipahami dan emuannya dapat diinformasikan kepada orang lain. Teknik analisis data yang digunakan dalam penelitian ini adalah deskriptif kualitatif. Analisis deskriptif kualitatif merupakan suatu teknik yng menggambarkan dan menginterpretasikan arti data-data yang telah terkumpul dengan memberikan perhatian dan merekam sebanyak mungkin aspek situasi yang diteliti pada saat itu. Sehingga memperoleh gambaran secara umum dan menyeluruh tentang keadaan sebenarnya serta memberikan ulasan atau interpretasi terhadap data yang diperoleh sehingga menjadi lebih jelas dan bermakna. Deskriptif kualitatif digunakan dalam penelitian tentang karakteristik, motivasi ini bertujuan untuk menjelaskan hasil persentase yang diperoleh dari karakteristik, serta skore skala likert dari motivasi wisatawan yang berkunjung ke daya tarik wisata pantai Lakey Desa Hu'u Kabupaten Dompu.

\section{HASIL DAN PEMBAHASAN}

Desa Hu'u adalah terletak di Kecamatan Hu'u Kabupaten Dompu Provinsi Nusa Tenggara Barat Indonesia luas wilayah 186,50 $\mathrm{km}^{2}$. Secara geografis Desa Hu'u ini terletak sekitar 25 kilometer dari pusat Kota Kabupaten Dompu ke arah selatan. Batas wilayah administrasi sebelah utara laut Flores dan Kabupaten Bima, sebelah timur Kabupaten Bima, sebelah selatan samudera Indonesia dan disebelah barat Kabupaten Sumbawa. Pusat pemerintahannya berada di Desa Rasabou Kecamatan Hu'u. masyarakat Desa Hu'u mayoritas berprofesi sebagai nelayan, petani, karena sumber daya alam yang dimiliki oleh Desa $\mathrm{Hu}$ 'u meliputi pegunungan dan laut yang memudahkan masyarakat lokal Desa Hu'u memilih profesi sebagai nelayan serta bertani, sebagian masyarakat Desa Hu'u juga memilih berprofesi sebagai pemandu wisata lokal karena Kecamatan Hu'u sangat terkenal dengan destinasi wisata pantai dan popular sebagai tempat wisata bahari terutama olahraga selancar (surfing). Salah satu daya tarik wisata yang sangat dikenal oleh masyarakat luas baik wisatawan lokal maupun wisatawan mancanegara adalah daya tarik wisata pantai 
Lakey.

Desa Hu'u merupakan Desa yang memiliki sumber daya alam yang bisa terbilang sangat baik, bukan hanya wilayah untuk bercocok tanam, bertani, serta melaut, akan tetapi Desa Hu'u memiliki sejumlah daya tarik wisata yang sangat berpotensi bahkan sudah dikembangkan dan dikenal oleh masyrakat luas, baik wisatawan domestik maupun wisatawan mancanegara. Desa hu'u merupakan salah satu desa yang terletak di kabupaten Dompu Provinsi Nusa Tenggara Barat yang memiliki beberapa daya Tarik wisata unggulan, baik dari wisata budaya, wisata buatan maupun wisata alam dan sejarah. Desa hu'u dikenal sebagai desa yang mempunyai peradaban kehidupan yang cukup panjang dengan corak beragam yang membentuk pola perkembangan pada beberapa zaman atau periode, sama halnya dalam sektor pariwisata Desa Hu'u. dengan berjalannya waktu pada awal tahun 1990an Pemerintah daerah Kabupaten Dompu merencanakan pengembangan sektor pariwisata Desa $\mathrm{Hu}$ 'u karena adanya beberapa wisatawan yang melakukan Traveller atau pemburu ombak terbaik untuk bermain surfing, dengan berjalannya waktu pantai Lakey semakin dikenal oleh masyarakat luas, baik wisatawan nusantara maupun wisatawan nusantara.

Untuk meningkatkan ekonomi masyarakat serta kesejahteraan masyarakat, pemerintah daerah Kabupaten Dompu, memanfaatkan potensi wisata yang terletak di Desa hu'u sebagai ikon pariwisata Kabupaten Dompu untuk jangka waktu panjang, hingga saat ini banyak upaya yang dilakukan pemerintah Kabupaten Dompu yang bertujuan untuk melancarkan aktivitas wisata serta mengembangkan sektor pariwisata kabupaten Dompu, seperti halnya, pembangunan sarana prasana penunjang kegiatan wisata seperti, toilet umum, gajebo tempat bersantai, area parkir. Bukan hanya itu, dari segi aksesibilitas pemerintah daerah Kabupaten Dompu juga telah melakukan pembangunan seperti, jalan raya, lampu jalan di sekitar daerah sekitar pantai Lakey, petunjuk arah jalan menjadi fasilitas pendukung untuk memudahkan wisatawan berkunjung ke beberapa daya Tarik wisata yang terletak di Desa Hu'u. dengan berjalannya waktu, penyediaan akomodasi di daya darik wisata yang terletak di Desa Hu'u sangat memadai, banyaknya infestor yang percaya bahwa potensi wisata yang dimiliki
Desa $\mathrm{Hu}$ 'u dapat menjadi wisata unggulan baik di kancah nasional maupun internasional. Dapat dilihat dari segi akomodasi yang disediakan untuk menunjang kegiatan wisata seperti, Hotel, Homestay, Bungalow, Villa, serta Resort, restoran, Mini bar, dan juga beberapa took soufenir, dan took yang menjual papan selancar. Semua fasilitas yang disedikan tersebut sebagai penunjang aktivitas wisata dan memudahkan wisatawan yang berkunjung ke daya Tarik wisata Desa Hu'u.

Pantai Lakey terletak dikecamatan Hu'u Desa Hu'u Kabupaten Dompu Nusa Tenggara Barat. Pantai Lakey adalah kawasan surfing terbaik dan unik di dunia, keunikan pantai Lakey berada pada sapuan ombak ke kiri bukan kanan sebagaimana meskinya bukan hanya itu, angin laut yang terbilang kencang di kawasan pantai Lakey sangat mendukung kegiatan berselancar, oleh karena itu keunikan dan potensi pantai Lakey menjadi daya tarik tersendiri bagi wisatawan yang memiliki minat khusus bermain selancar (surfing).

Pantai Lakey memiliki ombak yang terbilang stabil setiap tahunnya, (tidak terpengaruh musim) dan karenanya beberapa kali menjadi lokasi diadakannya kompetisi selancar tingkat dunia. Ratusan peserta kompetisi biasanya datang dari berbagai belahan dunia dan juga Indonesia. Keunggulan wisata pantai yang ditawarkan oleh pantai Lakey sebenarnya sudah terlihat pada pusat Kota Dompu ditandai dengan adanya patung orang yang tengah berselancar. Bagi penggila selancar, ombak besar dan tinggi memang sangat dicari tetapi ombak di pantai Lakey yang tidak terlalu tinggi ( sekitar 6-8 meter saja) justru jadi menantang ketika harus ditaklukan dengan arah ombak ke kiri yang membutuhkan keahlian khusus, wisatawan mancanegara sengaja datang jauh-jauh untuk mangasah keahliannya dalam berselancar (surfing).

Selain berselancar (surfing), wisatawan juga bisa berenang di pantai. Wisatawan wajib untuk behati-hati mengingat ukuran dan kekuatan gelombang di Pantai Lakey cukup kuat. Batuan yang berbahaya juga banyak tersebar di sepanjang pantai sekitarnya. Namun, air laut yang jernih dan kristal membuatnya menjadik situs baik untuk snorkeling. Ada titik-titik tertentu ditandai terutama untuk kegiatan snorkeling khusus karena keindahan terumbu karang dan berbagai ikan tropis untuk dilihat. Wisatawan yang berkunjung ke pantai Lakey juga dapat 
mengambil wisata tour melalui perairan sekitar pantai dengan menggunakan perahu sewaan. Bukan hanya itu, kehidupan masyarakat lokal sekitar daya tarik pantai lakey terbilang sangat unik serta masih mempertahankan adat istiadat, meskipun tidak di tunjang dengan pendidikan tinggi serta kurangnya pendidikan, akan tetapi masyarakat lokal Lakey sebagian besar memiliki kemampuan untuk bermain surfing sehingga menjadi atlet dan mengikuti event-event internasional baik dalam neeri maupun luar negeri, bahkan hamper sebagian besar masyarakat lokal Lakey dapat menggunakan bahasa asing dengan baik, Khususnya bahasa inggirs. Tidak hanya event surfing internasional, akan tetapi event-event seperti kuliner serta Festival Budaya sering diadakan di kawasan daya tarik wisata Pantai Lakey, untuk mempertahankan eksistensi daya tarik wisata pantai Lakey di mata para wisatawan yang berkunjung.

Karakteristik wisatawan mancanegara dalam penelitian ini yang berhubungan dengan karakteristik wisatawan mancanegara yang berkunjung langsung ke daya tarik wisata pantai Lakey berdasarkan trip descriptor antara lain: (status perjalanan, informasi perjalanan, jenis akomodasi, jenis transportasi, dan pengorganisasian perjalanan) dan tourist descriptor merupakan pembagian karakteristik sosio demografis, sosio psikografis, dan sosio geografis antara lain: (karakteristik sosio demografis: jenis kelamin, umur, status perkawinan, tingkat pendidikan, pekerjaan), (sosio psikografis, ingin berinteraksi dengan masyarakat lokal, untuk bersenang-senang, olahraga, daya tarik wisata menarik untuk dikunjungi), dan (karakteristik geografis: asal daerah tempat tinggal) pada wisatawan mancanegara yang melakukan perjalanan ke daya tarik wisata pantai Lakey Desa Hu'u Kabupaten Dompu. Terlihat bahwa dari 100 responden wisatawan mancanegara nn kelompok umur 15-30 tahun sebanyak yaitu 57 orang $(57 \%)$ wisatawan mancanegara yang berkunjung ke daya tarik wisata pantai Lakey Desa Hu'u Kabupaten Dompu. Untuk kelompok umur 31-46 tahun berjumlah 35 orang $(35 \%)$ wisatawan mancanegara, sedangkan kelompok umur 46 tahun ke atas adalah tingkat umur terendah yaitu 8 orang (8\%) wisatawan mancanegara yang berkunjung ke daya tarik wisata pantai Lakey Desa Hu'u Kabupaten Dompu. Data tersebut dapat dijelaskan bahwa karakteristik umur wisatawan mancanegara paling dominan yang mengadakan perjalanan wisata ke daya tarik wisata pantai Lakey adalah berkisaran pada umur 15 - 30 tahun.

Wisatwan mancanegara yang berasal dari Australia menempati urutan pertama dengan jumlah sebanyak 41 orang (41\%), selanjutnya urutan kedua ditempati oleh wisatawan mancanegara yang berasal dari Norwey dengan jumlah 8 orang (8\%), urutan selanjutnya yaitu wisatawan mancanegara yang berasal dari Spain, Italy, Canada yang masing- masing berjumlah 7 orang (7\%), sedangkan urutan selanjutnya yaitu berasal dari Brazil berjumlah 6 orang $(6 \%)$, urutan selanjutnya yaitu berasal dari Sweden dan Germany yang masing-masing berjumlah 5 oran $(5 \%)$, urutan selanjutnya yaitu berasal dari Slovakia yang berjumlah 4 orang (4\%), urutan selanjutnya yaitu wisatawan mancanegara yang berasal dari Japan yang berjumlah 3 orang (3\%), urutan selanjutnya yaitu berasal dari Thailand dan Argentina masing-masing berjumlah 2 orang (2\%), sedangkat urutan terakhir yaitu wisatawan mancanegara yang berasal dari France, Portugal, Belgium masing-masing berjumlah 1 orang (1\%). Dapat disimpulkan bahwa wisatawan mancanegara yang berkunjung ke daya tarik wisata pantai Lakey Desa Hu'u Kabupaten Dompu mayoritas berasal dari Australia dan Negara- Negara Benua Eropa lainnya seperti Norwey, Spain dan Italy. Hal ini dikarenakan secara potensi daya tarik wisata pantai Lakey merupakan salah satu tampat terbaik untuk para peselancar untuk bermain surfing.

Wisatawan mancanegara dalam penelitian yang dilakukan saat ini, bahwa wisatawan bmancanegara yang berkunjung langsung ke daya tarik wisata pantai Lakey yang berjenis kelamin laki- laki berjumlah 65 orang $(65 \%)$, sedangkan wisatawan mancanegara yang berjenis kelamin perempuan berjumlah 35 orang (35\%) berdasarkan data yang didapatkan tersebut menunjukan bahwa wisatawan mancanegara yang berjenis kelamin laki-laki lebih dominan untuk melakukan perjalanan ke daya tarik wisata pantai Lakey Desa Hu'u Kabupaten Dompu di bandingkan dengan wisatawan mancanegara yang berjenis kelamin perempuan.

Wisatawan mancanegara dalam penelitian ini, maka mayoritas berstatus 
Menikah berjumlah 52 orang (52\%), sedangkan berstatus belum menikah berjumlah 48 orang (48\%), sehingga dapat diketahui bahwa jumlah wisatawan mancanegara dengan status Menikah lebih banyak melakukan kegiatan perjalan wisata ke daya tarik wisata pantai Lakey meskipun dengan jumlah perbedaan tidak cukup jauh.

Wisatawan mancanegara dalam penelitian ini, paling dominan berprofesi sebagai wiraswasta berjumlah mencapai 59 orang (59\%) dan sedangkan wisatawan mancanegara yang berprofesi sebagai pegawai swasta sebanyak 42 orang (42\%) sedangkan di urutan ketiga wisatawan mancanegara yang berprofesi sebagai pelajar atau mahasiswa sebanyak 5 Orang (5\%), dan yang terakhir paling sedikit wisatawan mancanegara yang melakukan perjalanan wisata ke daya tarik wisata pantai Lakey berprofesi sebagai pegawai negeri sipil sebanyak 4 orang (4\%). Sehingga dapat disimpulkan bahwa wisatawan mancanegara yang berkunjung ke daya tarik wisata pantai Lakey yang berprofesi sebagai wiraswasta lebih berdominasi dalam melakukan kegiatan perjalanan wisata ke daya tarik wisata pantai Lakey Desa $\mathrm{Hu}$ 'u Kabupaten Dompu.

Dari 100 responden wisatawan mancanegara yang melakukan perjalanan wisata ke daya tarik wisata pantai Lakey mayoritas latar belakang pendidikan Sekolah menengah atas (SMA) berjumlah 54 orang (54\%). Sedangkan Diploma atau akademi berjumlah mencapai 29 orang (29\%), dan terakhir Universitas berjumlah 17 orang $(17 \%)$. Sehingga dalam penelitian ini dapat menunjukan bahwa wisatawan mancanegara dengan latar belakang pendidikan Sekolah menengah atas paling dominan dalam memilih melakukan perjalanan wisata ke daya tarik wisata pantai Lakey Desa Hu'u Kabupaten Dompu Provinsi Nusa Tenggara Barat.

Wisatawan mancanegara yang melakukan perjalanan wisata ke daya tarik wisata patai Lakey dalam hal status perjalanan dominan karena ingin rekreasi ata liburan sebanyak 98 orang (98\%). Sedangkan wisatawan mancanegara yang melakukan perjalanan wisata ke daya tarik wisata pantai Lakey karena ingin mengunjungi keluarga atau teman berjumlah 2 orang (2\%). Sehingga dapat disimpulkan dalam penelitian ini bahwa wisatawan yang melakukan perjalanan wisata ke daya tarik wisata pantai Lakey karena ingin rekreasi atau liburan.

Wisatawan mancanegara yang melakukan perjalanan ke daya tarik wisata pantai Lakey dalam penelitian ini, kebanyakan memperoleh informasi dari teman atau keluarga dengan jumlah mencapai 54 orang (54\%), untuk mendapat informasi dari Media cetak magazines, brochures, newspaper dengan berjumlah mencapai 33 orang (33\%), dan selanjutnya yang mendapatkan informasi dari Media sosial seperti facebook, instagram, path lain-lain berjumlah mencapai 7 orang, sedangkan sumber informasi wisatawan mancanegara yang memiliki jumlah paling sedikit adalah Media elektronik seperti Tv, internet, radio berjumlah 4 orang (4\%). Sedangkan sisanya memiliki alasan lain mendapat informasi dengan Traveling. Berdasarkan data tersebut maka disimpulkan bahwa wisatawan mancanegara yang melakukan kegiatan perjalanan wisata ke daya tarik wisata pantai Lakey memperoleh informasi dari teman atau keluarga.

Dari 100 responden wisatawan mancanegara dalam penelitian ini, kebanyakan frekuensi berkunjung wsatawan ke daya tarik wisata pantai Lakey dengan frekuensi kunjungan sebanyak 2-3 kali berjumlah 63 orang $(63 \%)$, berikutnya dengan jumlah kunjungan lebih dari 5 kali berjumlah 23 orang (23\%), berikutnya dengan jumlah kunjungan 1 kali sejumlah 12 orang, dan yang terakhir dengan jumlah kunjungan 4 kali adalah 2 orang $(2 \%)$. Berdasarkan data tersebut, maka dapat disimpulkan bahwa wisatawan mancanegara yang melakukan perjalanan ke daya tarik wisata pantai Lakey telah berkunjung sebanyak 2-3 kali.

Wisatawan mancanegara dalam penelitian ini, kebanyakan menginap di home stay dengan jumlah mencapai 59 orang (59\%), berikutnya yaitu menginap di hotel dengan jumlah 28 orang (28\%), berikutnya yaitu, sebanyak 13 orang (13\%) lainnya wisatawan mancanegara yang berkunjung ke daya tarik wisata pantai Lakey memiliki alasan tersendiri dengan memilih lain-lain, seperti menginap di villa pribadi, bungalow pribadi. Berdasarkan data tersebut maka dapat disimpulkan bahwa wisatawan mancanegara yang melakukan perjalanan wisata ke daya tarik wisata pantai Lakey kebanyakan menginap di home stay.

Wisatawan mancanegara yang menggunakan jenis transportasi kebanyakan transportasi udara dengan jumlah mencapai 58 
orang $(58 \%)$, berikutnya menggunakan transportasi darat dengan berjumlah 33 orang (33\%), dan yang terakhir yaitu transportasi air dengan jumlah 9 orang (9\%). Berdasarkan data tersebut maka dapat disimpulkan bahwa wisatawan mancanegara yang melakukan perjalanan wisata ke daya tarik wisata pantai Lakey Desa Hu'u Kabupaten Dompu Provinsi Nusa Tenggara Barat kebanyakan dengan menggunakan transportasi udara.

Wisatawan mancanegara dalam penelitian ini, kebanyakan alasan wisatawan mancanegara yang memilih berkunjung ke daya tarik wisata pantai Lakey adalah menarik untuk dikunjungi berjumlah 93 orang $(93 \%)$, berikutnya dengan alasan biaya lebih murah dengan jumlah 5 orang $(5 \%)$, sedangkan 2 wisatawan lainnya memilih lain-lain dengan alasan mengunjungi keluarga. Berdasarkan data tersebut, maka dapat disimpulkan bahwa wisatawan mancanegara yang berkunjung ke daya tarik wisata pantai Lakey Desa Hu'u Kabupaten Dompu Provinsi Nusa Tenggara Barat mayoritas alasan adalah karena menarik untuk di kunjungi berjumlah 93 orang (93\%).

Wisatawan mancanegara dalam penelitian ini, di dominasi oleh wisatawan dengan waktu lama tinggal di daya tarik wisata pantai Lakey lebih dari lima hari (> 5 Hari) sebanyak 45 orang (45\%), berikutnya dengan waktu lama tinggal tiga sampai lima hari (3-5 Hari) berjumlah 39 orang (39\%), dan yang terakhir dengan waktu lama tinggal satu sampai tiga hari (1-3 Hari) berjumlah 16 orang (16\%). Berdasarkan data tersebut, maka dapat disimpulkan bahwa wisatawan mancanegara yang berkunjung ke daya tarik wisata pantai Lakey di dominasi oleh waktu tinggal lebih dari lima hari (>5 Hari).

Wisatawan mancanegara dalam penelitian ini. Mayoritas pengorganisasian sendiri berjumlah 68 orang $(68 \%)$, berikutnya teman/keluarga berjumlah 24 orang (24\%), berikutnya, biro perjalanan wisata berjumlah 6 orang $(6 \%)$, sedangkan sisa 2 orang mimilih lainnya. Berdasarkan data tersebu, maka dapat disimpulkan bahwa wisatawan mancanegara yang berkunjung ke daya tarik wisata pantai Lakey Desa Hu'u Kabupaten Dompu mayoritas pengorganisir adalah sendiri berjumlah 68 orang $(68 \%)$.

Wisatawan melakukan suatu perjalanan sudah tentu didorong oleh motivasi- motivasi yang dimiliki oleh wisatawan yang menjadi alasan mereka untuk mengunjung suatu destinasi wisata atau daya tarik wisata dapat berasal dari dalam diri mereka atau motivasi atau motivasi intrinsik ataupun berasal dari luar diri mereka atau lingkungan dan bias disebut dengan motivasi ekstrinsik. Pada sub bab berikut akan dijelaskan hasil dari penelitian mengenai motivasi instrisik dan motivasi ekstrinsik wisatawan mancanegara berkunjung ke daya tarik wisata Pantai Lakey Desa Hu'u Kabupaten Dompu Provinsi Nusa Tenggara Barat.

Motivasi Intrinsik adalah dorongan atau komitmen yang berasal dari diri wisatawan untuk berkunjung ke daya tarik wisata pantai Lakey Desa Hu'u Kabupaten Dompu Provinsi Nusa Tenggara Barat. Adapun motivasi intrinsik wisatawan mancanegara berkunjung ke daya tarik wisata pantai Lakey Desa Hu'u Kabupaten Dompu di bagi kedalam 13 indikator.

Motivasi instrinsik wisatawan mancanegara yang berkunjung ke daya tarik wisata pantai Lakey Desa Hu'u Kabupaten Dompu menunjukan bahwa indikator motivasi instrinsik berupa ingin bersenang senang memiliki skor likert sebesar 4,12 (setuju), Skor tersebut masuk ke dalam kategori sikap kuat. Yang artinya wisatawan mancanegara yang melakukan perjalanan wisata ke daya Tarik wisata pantai Lakey termotivasi karena ingin bersenang-senang melakukan aktifitas seperti, melakukan perjalanan tour kepererairan pantai Lakey, bermain kano, dan lain sebagainya dapat dilihat dari karakteristik wisatawan yang berkunjung ke daya tarik wisata pantai Lakey.

Sedangkan, indikator motivasi instrinsik yang memiliki skor likert lebih rendah terdiri dari beberapa indikator pada rentang yang sama yaitu pada kategori sikap setuju secara berurutan adalah sebagai berikut, ingin menyalurkan hobi bermain selancar/ surfing dengan skor liket sebesar 4,09 (setuju), yang artinya wisatawan mancanegara yang melakukan perjalanan wisata ke daya Tarik wisata pantai Lakey termotivasi karena ingin menyalurkan hobi bermain selancar. selanjutnya ingin menikmati alam dengan skor liket 4,04 (setuju), yang artinya wisatawan mancanegara yang melakukan perjalanan wisata ke daya Tarik wisata pantai Lakey termotivasi karena ingin menikmati alam dapat diliha dari karakteristik umur wisatawan yang berkunjung ke pantai Lakey di dominasi umur 15 hingga 30 tahun dan juga karakteristik wisatawan mancanegara dengan alasan 
berwisata di dominasi karena pantai Lakey memiliki potensi yang menarik yaitu wisata alam, wisata budaya serta kehidupan masyarakat yang unik.

Selanjutnya, ingin berinteraksi dengan masyarakat lokal Desa Hu'u mendapat skor likert 3,96 (setuju), yang artinya wisatawan mancanegara yang berkunjung ke daya Tarik wisata pantai Lakey termotivasi karena berinteraksi dengan masyarakat lokal Desa Hu'u. selanjutnya, keluar dari rutinitas dengan skor likert 3,88 (setuju), yang artinya wisatawan mancanegara yang melaukan perjalanan wisata ke daya Tarik wisata pantai Lakey termotivasi karena ingin keluar dari rutinitas. Selanjutnya, Untuk mengetahui kesenian Kabupaten Dompu, pakaian adat, serta budaya dengan skor liker 3,48 (setuju), yang artinya wisatawan mancanegara yang melakukan perjalanan wisata ke daya Tarik wisata pantai Lakey termotivasi karena ingin mengetahui budaya serta adat istiadat Kabupaten Dompu. Selanjutnya, Untuk mengetahui kehidupan Desa Hu'u dan gaya hidup masyarakat lokal Desa Hu'u dengan skor likert 3,46 (setuju), yang artinya wisatawan mancanegara yang melakukan perjalanan wisata ke daya Tarik wisata pantai Lakey termotivasi karena ingin mengetahui kehidupan masyarakat lokal Desa Hu'u.

Dapat dilihat dari karakteristik wisatawan mancanegara dari segi umur yang di dominasi umur 15 hingg 30 tahun keatas dan juga dari segi karakteristik dan status perjalanan di dominasi untuk wisata.

Sedangkan motivasi instrinsik wisatawan mancanegara pada indikator yang mendapatkan skor likert dalam kategori cukup kuat adalah Untuk melihat-lihat dengan skor likert sebesar 2,79 (ragu-ragu), yang artinya wisatwan mancanegara yang melakukan perjalanan wisata ke daya tarik wisata pantai Lakey termotivasi karena ingin melihat-lihat kurang kuat dari indikator-indikator sebelumnya.

Selanjutnya 2 indikator motivasi instrisik yang memilik skor likert terendah dengan kategori tidak kuat adalah ingin mengetahui sejarah Desa Hu'u dengan skor likert 2,46 (tidak setuju), Ingin mengunjungi teman/ keluarga dengan skor likert 2,15 (tidak setuju). Dari hasil diatas maka dapat diperoleh hasil bahwa motivasi yang berdominasi adalah wisatawan mancanegara melakukan perjalan wisata ke daya Tarik wisata pantai Lakey termotivasi karena ingin bersenang senang diikuti oleh indikator ingin menyalurkan hobi bermain selancar/ surfing. Jika dilihat lebih jauh motivasi ini dapat menjadi motivasi instrinsik yang tertinggi jika dikaitkan dengan karakteristik yang mendominasi wisatawan mancanegara pada penelitian ini adalah berumur 15-30 dan 31-46 tahun dengan pekerjaan wiraswasta dan memiliki hobi khusus bermain selancar/ surfing yang memiliki pendapatan yang cukup untuk melakukan perjalanan wisata dan memiliki waktu luang untuk melakukan perjalanan wisata ke daya tarik wisata pantai Lakey Desa Hu'u Kabupaten Dompu Provinsi Nusa Tenggara Barat.

Motivasi ekstrinsik adalah dorongan atau kemauan yang sumbernya bukan dari dalam diri wisatawan mancanegara melainkan dipengaruhi oleh faktor eksternal seperti keunikan daya tarik wisata, adanya ajakan dari teman/keluarga untuk melakukan perjalanan wisata atau adanya waktu luang dari wisatawan mancanegara yang berkunjung ke daya tarik wisata pantai Lakey serta biaya perjalanan terjangkau hingga study tour.

Berdasarkan data Tabel 4.17 dalam penelitian yang dilakukan saat ini tentang motivasi ekstrinsik wisatawan mancanegara yang berkunjung ke daya tarik wisata pantai Lakey Desa Hu'u Kabupaten Dompu menunjukan bahwa motivasi ekstrinsik tertinggi adalah pada indikator adanya waktu luang untuk melakukan perjalanan wisata ke daya tarik wisata pantai Lakey dengan skor likert sebesar 4,27 (sangat setuju).

Dapat dilihat dari karakteristik wisatawan mancanegara dari segi status pendidikan yang bukan pelajar akan tetapi pekerja wiraswasta yang lebih memiliki waktu luang untuk berwisata dan pendapatan ekonomi yang mampu untuk melakukan perjalanan wisata. skor liker tersebut memiliki arti bahwa wisatawan mancanegara secara ekstrinsik termotivasi oleh adanya waktu luang untuk mengunjungi daya tarik wisata pantai Lakey. selanjutnya motivasi ekstrinsik yang memiliki skor likert tertinggi kedua adalah ajakan teman/ keluarga sebesar 4,07 (setuju) dapat diartikan bahwa wisatawan yang berkunjung ke daya Tarik wisata pantai Lakey termotivasi karena ajakan teman/keluarga memiliki skor liker tertinggi kedua. Dapat di lihat dari karakteristik wisatawan mancanegara dari segi informasi tentang daya tarik wisata di 
dominasi oleh informasi dari teman/keluarga sehingga motivasi kunjungan wisatawan karena ajakan teman/ keluarga. dan selanjutnya beberapa indikator yang memiliki skor likert rentang sama dengan kategori setuju. adalah biaya perjalanan yang terjangkau mendapat skor likert sebesar 4,02 (setuju) artinya wisatawan mancanegara yang melakukan perjalanan wisata ke daya Tarik wisata pantai Lakey termotivasi karena biaya perjalanan ke daya Tarik wisata pantai Lakey terjangkau, dan selanjutnya keunikan daya tarik wisata pantai Lakey mendapat skor likert sebesar 4,00 (setuju), artinya wisatawan mancanegara yang berkunjung ke daya Tarik wisata pantai Lakey termotivasi karena keunikan daya Tarik wisata pantai Lakey,

Dapat dilihat dari beberapa karakteristik wisatawan mancanegara dari segi pekerjaan di dominasi oleh wisraswasta yang memiliki penghasilan yang cukup untuk melakukan perjalanan wisata dan juga karakteristik wisata dari segi alasan berkunjung di dominasi oleh keunikan daya tarik wisata yang menarik wisatawan untuk berkunjung ke daya tarik wisata pantai Lakey.

Sedangkan skor likert paling rendah motivasi ekstrinsik pada indikator melakukan studi banding mendapatkan skor likert sebesar 2,16 (tidak setuju). Berdasarkan Tabel tersebut maka dapat disimpulkan bahwa dari lima indikator motivasi ekstrinsik yang menjadi indikator yang mendominasi motivasi ekstrinsik wisatawan mancanegara berkunjung ke daya tarik wisata pantai Lakey Desa Hu'u Kabupaten Dompu adalah adanya waktu luang untuk melakukan perjalanan wisata, jika diteliti lebih jauh motivasi ekstrinsik yang berdominasi pada penelitian ini adalah adanya waktu luang untuk melakukan perjalanan wisata, disebabkan karena karakteristik yang berdominasi adalah para orang dewasa dengan pekerjaan sebagai wiraswasta dan memiliki hobi bermain surfing serta memiliki pendapatan yang cukup untuk melakukan perjalanan wisata ke daya Tarik wisata pantai Lakey dan juga lebih memiliki waktu luang untuk melakukan perjalanan wisata ke daya tarik wisata pantai Lakey Desa Hu'u Kabupaten Dompu Provinsi Nusa Tenggara Barat.

\section{SIMPULAN \\ Simpulan}

Karekteristik mancanegara yang berkunjung ke daya tarik wisata pantai Lakey adalah mayoritas berjenis kelamin laki laki dan perempuan, berusia 15 hingga 30 dan 31 hingga 46 tahun, daerah asal di dominasi Negara Australia, status perkawinan menikah dan pekerjaan sebagai wiraswasta di latar belakangi pendidikan sekolah menengah atas (SMA), dan memperoleh informasi dari teman/ keluarga.

Motivasi instrinsik dan motivasi ekstrinsik wisatawan mancanegara yang berkunjung ke daya tarik wisata pantai Lakey Desa Hu'u Kabupaten Dompu Provinsi Nusa Tenggara Barat adalah mayoritas untuk bersenang senang, seperti bersantai menikmati pantai Lakey, melakukan tour dengan menggunakan boat sewaan, bermain kano, dan aktifitas wisata lainnya, dan selanjutnya menyalurkan hobi bermain selancar atau surfing, menikmati alam dan juga untuk berinteraksi dengan masyarakat lokal dan bertemu orang baru, sedangkan motivasi ekstrinsik adalah mayoritas dikarenakan adanya waktu luang untuk melakukan perjalanan wisata, keunikan daya tarik wisata pantai Lakey, biaya perjalanan yang terjangkau serta ajakan dari teman/ keluarga.

\section{Saran}

Untuk meningkatkan wisatawan mancanegara yang berkunjung ke daya tarik wisata pantai Lakey, maka pemerintah daerah serta para pelaku usaha pariwisata di daerah daya tarik wisata pantai Lakey perlu meningkatkan promosi dan memperluas kerja sama dengan travel agen lain mengenai daya tarik wisata yang ada di daerah Desa Hu'u serta Kabupaten Dompu. Sehingga kunjungan wisatawan dapat tersebar dengan baik.

$$
\text { Pemerintah daerah lebih }
$$

memperhatikan transportasi umum agar memudahkan wisatawan untuk berkunjung ke daya tarik wisata pantai Lakey agar memudahkan wisatawan yang ingin 
berkunjung, karena jarak daya tarik wisata pantai Lakey dengan pusat kota terbilang cukup jauh.

Sebaiknya pemerintah daerah Kabupaten Dompu lebih memperhatikan aksesibilitas seperti lampu jalan, rambu lalu lintas dan pos penjagaan polisi agar keamanan wisatawan yang berkunjung ke daya tarik wisata pantai Lakey dapat terjaga dengan baik.

Pemerintah daerah Kabupaten Dompu perlu meningkatkan fasilitas fisik sarana prasarana agar mendukung kegiatan wisata di daya tarik wisata pantai Lakey serta kepuasan wisatawan yang berkunjung dapat terwujud. 


\section{Kepustakaan}

Abubakar, 2009, Populasi Dan Sampel Penelitian 4: Ukuran Sampel Rumus Slovin, Erlangga, Jakarta.

Alister Mathieson and Geoffrey Wall. 1982. Tourism: Economic, Physical and Social Impact. New York. Longman Scientific and Technical.

Badan Pusat Statistik, Kabupaten Dompu, Tahun 2018. Jumlah Kunjungan wisatawan Mancanegara di Pantai Lakey Desa Hu'u.

Bennet, Seaton, 1996, Marketing Tourism Products, Oxford: Alden Press.

Cohen, Erik. (1984). The Sociology of Tourism: Approeches, Issues, and Finding.

California: Annual Review of Sociology, Vol. 10.

Dinas Pariwisata Kabupaten Dompu. Peta Pariwisata Kabupaten.

Dinas Pariwisata Kabupaten Dompu. 2014. Dompu. Data pariwisata Desa Hu'u.

Gartner, William C. 1996. Tourism Development : Principles, Processes, and Policies. USA : Van Nostrand Reinhold.

James , Spillane, J. (1982:20). Pariwisata Indonesia, Sejarah dan Prospeknya.

McIntosh. 1997. Karakteristik Wisatawan. Yogyakarta: Penerbit Andi.

, Goelder and Rithchin. 2004. World Tourism Organizatio.

TourismBarometer. Madrid: WTO.

Muljadi AJ, Andri. 2014. Kepariwisataan dan Perjalanan. Edisi Revisi. Jakarta: PT. Raja Grafindo Persada.

Murphy. 1985. Pengembangan Potensi Pariwisata.Bandung: Penerbit Alfabeta.
, P.E. 1985. Tourism: A Community Approach. New York and London: Routledge.

Smith, T. W. (1989). The hardy personality: cognitve and physiological responses to evaluative threat. Journal of Personality and Social Psychology, Vol. 56, No.2, 257-266.

, Stepehen L.J 1995. Tourism Analysis a HardBook. Logman Scientific \& Technical.

Sugiyono.2006.Metode Penelitian Kuantitatif, Kualitatif dan R \& D.Bandung:Alfabeta. , Sugiyono. (2000). Statistika utuk Penelitian, Bandung: Alfabeta.

, 2014, Metode Penelitian Administrasi Dilengkapi dengan Metode R\&B Bandung: Alfabeta.

Suwantoro, Gamal. 2004. Dasar-dasar Pariwisata. Penerbit Andi Yogyakarta.

Suyitno, Perencanaan Wisata. Yogyakarta: Penerbit Kanisius.

Slamet, Y.,1993. Analisis Kuantitatif Untuk Data Sosial. Solo : Dabara Publisher.

, 2007. Strategi Pemasaran. Edisi Kedua, Yogyakarta: Andi offset. Undang-undang No. 10 Tahun 2009 tentang Kepariwisataan. 